\title{
AN ANALYSIS OF PSYCHOPATHIC TRAITS TOWARDS ANNIE WILKES IN MISERY NOVEL BY STEPHEN KING
}

\author{
Sri Yadriha, Ana mariana \\ English Literature Department, Cultural Sciences Faculty, \\ Muhammadiyah University of Gorontalo
}

\begin{abstract}
Psychopath is abnormal psychology that cause pasients have difficulty in adjusting to the social norms that exsist in the environment. Basically psychopath is more known as a social predator because they likes to kill and rape their victims. This research focused on the psychopathic traits in one of the character in Misery novel named Annie Wilkes. This research used descriptive qualitative method and Robert D. Hare's theory to reveal psychopathic traits shown by Annie Wilkes. The result of this research, there are eleven psychopathic traits in Annie Wilke. That are egocentric, lack of empathy, lack of concern for others, impulsivity, poor behavioral control, have an attractive outward appearrance, shallow emotions, have no fear, high posses feelings for personal satisfication, have a cruel social relationship with others and anti-social.
\end{abstract}

Keywords : Psychopath, Abnormal Psychology, Psychopathic Traits.

\section{INTRODUCTION}

Generally, psychology is one of the areas of science that examines the human soul. Minderop (2010: 3) stated that, psychology comes from the Greek psyche, meaning soul and logos which means science. The psychology is the study of the human soul. The objects in psychology are soul and behaviour. The soul as an object of psychology cannot be seen or touched. The soul can only be observed through the results it produces. This can be known from the behaviour and other activities. Through behaviour, someone personality can be easily to reveal, such as how to eat, walk, talking, crying, or laughing is an open act. Whereas closed deeds can be seen from behaviour, like thinking, fear, calm, passive and withdraw from the environment. According to Chaer (2003: 2) psychology is commonly defined as one a field of science that tried to study about human behaviour. 
Since the existence of the science of psychology at the end of the 18th century, personality has always been become an important topic to discussion. Psychology is studied as a science to understand the whole person, which can only be done through understanding about personality, Alwisol (2009: 1).

The main part of psychology is personality that is often studied to know the character of a person. Heuken (1979: 10) said that, personality are the overall pattern of all the abilities, deeds and habits of a person, either the physical, the mental, the spiritual, the emotional as well as the social.

Abnormal psychology is the abnormal behavior that exist in the individual soul. Psychological or biological factors are also able to trigger the abnormal to the psyche. Fausiyah \& Widury, (2008: 4) stated that, abnormal behavior has the same meaning as behavioral disorder, mental disorder or mental illness, and emotional disturbance. One of the disorders of abnormal psychology is psychopath. According to Dirgagunarsa (1998: 145) psychopaths are abnormal psychology that cause patients have difficulty in adjusting to the social norms that exist in the environment. Causes a person to suffered from psychopaths because of the lack or absenced of affection received from their environment. Psychopaths as predators that used attraction, manipulation, intimidation, and violence to control a person to satisfy their selfish. Psychopaths have a lack of conscience and feelings towards others.

Based on the above explanation, the researcher is interested to analyze the human's abnormal psychology especially in psychopathic traits. Psychopathic traits contained in the main character named Annie Wilkes in the Misery novel by Stephen King.

Misery is a novel by Stephen King which tells about a woman named Annie Wilkes who got abnormal psychology that is psychopath. It was first published on 1987, in the United Stated. The novel was nominated for the World Fantasy Award for Best Novel. For that reasons, the researcher is interested in 
analyzing the novel by giving the title "An Analysis of Psychopathic Traits Towards Annie Wilkes in "Misery" novel by Stephen King”.

\section{RESEARCH METHOD}

This research used qualitative method. Qualitative method is a process of research and understanding based on methodology that investigated a social phenomenon and human problem. According to Creswell (in Herdiansyah, 2010: 8) qualitative research is an inquiry process of understanding based on distinct methodological traditions of inquiry that explored a social or human problem, the researcher builds a complex, holistic picture, analyzed words, report detailed views of information, and conducted the studied in a natural setting. Qualitative method is emphasize with meaning and value and used to know the hidden meaning, to develop theory, and understand social interaction and human psychology.

\section{Research Finding And Discussion}

\section{Egocentric}

Psychopaths had a very high selfishness, they even had their own rules. According to Hare (in Pemayun, 2017: 419) psychopaths have high self-esteem and make them look at others trivially, causing selfishness within them. This character believed that themself had overplus. Such as, most powerful, most correct, felt smarter and interesting. Because of that, they liked to controlled others to followed what they want.

Data 1 :

She told him she didn't think it was as good as his others. 'It's hard' she complained. 'It keeps jumping from one time to another. Paul swears all the time. Nearly every word is a swear-word.' That's true to life, Annie, don't you think?' Paul asked. 'No, they don't,' she said, giving him a hard look. (pg. 10)

In data 1, the quotation described the egocentric in Annie's personality. This is shows when Annie and Paul are having discussion and Paul gives his 
normal opinion. But in this case, Annie complained because it is not agree with her own opinion. She said that, Paul's opinion is hard to follow, then she giving Paul a hard look. Based on the description above, clarified that she felt the most correct and cannot accept other's opinion. The data has similarities with Hare's explanation that psychopaths believed themself are the most correct.

Data 2 :

'I was smarter than that. 'Looking at those cartons was the same as looking at the figures on the little parlor table I thought the stuff in them had been sort of stirred around, and I was pretty sure that one of the cartons that was on the bottom before was on top of some of the other cartons now, but I couldn't be sure. (pg. 21)

The data explained grandiose self worth in Annie's character. This is can be seen when she distrusted Paul about her some furniture's are a little mussy. She asserted Paul to knows that she knows everything happen although it was hidden. can be seen in Annie's words to Paul that, she was smarter than that. In the other sentence she also said that, she was pretty sure. Based on the description above, clearly that she has high self esteem. The data is supported Hare's theory that psychopaths believed themself smarter.

\section{Lack of Empathy}

Psychopaths are typcal who lack of empathy. According to Perri \& Lichtenwald (2010: 54) psychopaths have a lack of conscience and empathy feelings towards others. They did some ways to get what they want although it harm others and was contravened with the norms.

\section{Data 4 :}

'Now I must rinse,' she said, 'or else the soap will leave a dull spot. I must do it all; I must make everything right. 'Please, the pain, I'm dying.' 'No. You're not dying.' 'I'll scream,' he said, beginning to cry harder. It hurt to cry. It hurt his 
legs and it hurt his heart. 'I won't be able to help it.' 'Then scream,' she said.' (pg. 11)

In data 4, the lack of empathy showed by Annie when she still rinse the spilled of soup on Paul's bed. Paul screamed because he was pained and cannot moved. In this case, Annie shows her lack of empathy. She still did it and did not care about Paul's condition although she heard Paul's screamed. The data is relevant with Perri and Lichtenwald's theory that psychopaths has lack of conscience and feelings towards others. They did some ways to get what they want although it harm others.

In addition, because there is no empathy feelings in Annie, she became a person who lack of concern for others. Lack of empathy also related to lack of concern for others. This is indicated by an indifferent attitude towards the rights, feelings and safety of others. Even they can laugh at the misfortunes of others, even though she or he is the cause, Hare (in Stover, 2008: 155).

\section{Impulsivity}

According to Hare (in Stover, 2008: 159) revealed that generally, psychopaths has an impulsive personality, impulsivity personality by psychopaths can be seen when they did not think before to do an act and did it with following their own will.

Data 6 :

Now I must rinse,' she said, 'or else the soap will leave a dull spot. I must do it all; I must make everything right. 'Please, the pain, I'm dying.' 'No. You're not dying.' 'I'll scream,' he said, beginning to cry harder. It hurt to cry. It hurt his legs and it hurt his heart. 'I won't be able to help it.' 'Then scream,' she said.' (pg. 11)

The data was described about Annie's impulsivity character. Her impulsivity showed when she still rinse the spills of soup on the bed and didn't want the else of soup will leave a dull spot. She did it and make everything right 
although she knew that paul pained and cannot moved. Based on that statement, clearly that Annie has impulsive traits. The data is supported Hare's theory that generally, psychopaths has an impulsive personality. Impulsivity personality by psychopaths, can be seen when they don't think before to do an act. Psychopaths do an action with following their own will.

\section{Poor behavioral Control}

Psychopaths are typical people who are very difficult to control their behavior. According to Hare ( in Pemayun, 2017: 422) psychopaths tend to respond to a failure or criticism from others with sudden behavior.

\section{Data 7 :}

'It has no nobility!' she cried suddenly, jumping and almost spilling beefbarley soup on his white, upturned face. She looked at him, her face now like a sky which might spawn tornadoes at any instant. 'Sure! You! Are!' she screamed, and threw the bowl into the corner, where it shattered. Soup splashed up the wall. (pg. 10)

Poor behavioral control showed by Annie when she knew a truth she cannot accept. Annie who had been calm before, suddenly become very angry. She suddenly cried, jumped and threw a bowl of soup into the wall in the room. The data is relevant with Hare's theory that psychopaths tend to respond to a failure or criticism from others with sudden behavior.

Data 8 :

'I don't want her spirit!' she screamed, hooking her fingers into claws and shaking them at him, as if she would tear his eyes out. 'I want her! You killed her! You murdered her!' Her hands snapped shut into fists again and she drove them down like pistons, one on either side of his head. They punched deep into the pillow and he bounced like a ragdoll. His legs flared and he cried out. (pg. 14)

In data 8 , Annie become very angry because she knews that her favourite character in Paul's novel is died. Then She held Paul's head and shook it. Proved 
that she cannot control her behavior. The data is supported Hare's theory that psychopaths tend to respond to a failure or criticism from others with sudden behavior.

\section{Have an Attractive Outward Appearance}

Have an Attractive Outward Appearance is one of psychopathic traits that included in psychopathic checklist which conducted by Hare. Explanation Hare (in Stover 2008: 152) stated that, interesting appearance as their ability to speak fluently and make a lie, has been two face and has an attraction. When interacting, psychopaths look very attractive, smooth and entertaining. According to Hare (in Stover, 2008: 154) psychopaths made a manipulation until unaware by their victims. They are able to convince others by lying and telling positive things about themselves. That way, they will be entirely trusted by others.

Data 9 :

He had screamed! And when I heard you screaming, I knew that you would live. Dying men rarely scream. They haven't the energy. I know. I decided I would make you live. So, I got some of my pain medication and made you take it. Then you went to sleep. When you woke up and started to scream again, I gave you some more. You ran a fever for a while, but I knocked that out, too. I gave you Keflex. You had one or two close calls, but that's all over now. I promise.' She got up. And now it's time you rested, Paul. You've got to get your strength back.' (pg.7)

In data 9, Attractiveoutward appearance showed by Annie when she talks to Paul about her efforts to saved Paul's life. She explained to paul, when the accident, Paul screamed because of his pain then he unconscious. Annie convinced Paul how afraid she was at that incident. She said that she would make Paul live, then took Paul in her house, nursed him and gave him some medicine. Based on the description above, clearly that Annie tried to tells positive things about her to make Paul believe that she is a good woman. This data is supported 
Hare's theory that psychopaths had abilities to speak fluently when conviced others.

Data 10 :

'My legs hurt.' Said Paul. 'Yes, I'm sure they do. In an hour you can have some medication.' 'In an hour.' Firmly. She moved toward the door with the spoon and the soup-bowl in one hand. 'Wait!' She turned back, looking at him with ail expression both stern and loving. (pg. 6)

In data 10, Annie showed her good attitude with gave a very convinced facial expression. This is happened when Paul screamed because of his pain and desperately need a medicine. In this case, quickly Annie look at Paul with ail expression, both stern and loving. The expression on her face showed as if she could not see Paul suffering. In this way, Paul will attracted and assumed that Annie is a very kind and pleasant woman. Based on the description above, proved that Annie used her charm to make Paul believe about her kindness. The data is supported Hare's theory that psychopaths are had ability to influenced others with used their two faced when interact.

In addition, because there is no empathy feelings in Annie, she became a person who lack of concern for others. Lack of empathy also related to lack of concern for others. This is indicated by an indifferent attitude towards the rights, feelings and safety of others. Even they can laugh at the misfortunes of others, even though she or he is the cause, Hare (in Stover, 2008: 155).

\section{Shallow Emotions}

A psychopath has shallow emotions. Explanation Hare (in Hirstein 2005: 91) concluded that, psychopaths lack of conscience because they cannot to feel the emotional deeply. Like fear, remorse, sadness and anxiety in their life. After committing a crime such as rape, violence and murder, there is no guilt in 
psychopaths even though they are awared was done a wrong action. Psychopaths does not care to what happen, and assumed like nothing happen.

Data 13 :

'You killed him,' Paul said. His voice sounded dim and ancient. She smiled uneasily at the wall. 'Well, I guess it was something like that. I don't remember very well. Just when he was dead. I remember that. She smiled. (pg. 21)

In data 13, the quotation was about Annie's confessed that she had killed a man. it happened when Paul asked Annie if she had killed him. She smiled uneasily at the wall and answered and said, it was something like that. In this case, after doing a bad acts there was no remorse in her. The data is relevant with Hare's theory that after comitting a crime like murder, there is no remorse in psychopaths even though they awared was done a wrong action.

Data 14 :

Just a little pain, Paul. It won't be bad.' She turned the axe over and splashed the other side of the blade. Oh annie please let me be good.' 'Just a little pain. Then

this nasty business will be behind us for good, Paul.' Dark-red blood splattered across her face like Indian war-paint. It splattered the wall.

In data 14, with sadistic attitude, Annie broke Paul's legs used an ax. Without showing any guilt she said to Paul that it was only a little pain and would not be bad. in this case, proved that Annie did not felt remorse after committing a crime. The data is supported Hare's theory that after comitting a crime such as violence, there is no remorse in psychopaths

even though they are awared was done a wrong action.

Beside shallow emotion, Annie's character is also included in one of psychopathic checklist, have no fear. Because of her shallow emotions, Annie cannot feel fear of what had happened. This is shown when she has done a wrong action like criminal, there is no fear or anxiety in her. The relation between 
shallow and have no fear traits was relevant with Hare's theory that psychopaths lack of conscience because they cannot to feel the emotional deeply. Like fear, remorse, sadness and anxiety in their life.

\section{High Posses Feelings for Personal Satisfication}

The trait high posses feelings for personal satisfication is a habit of psychopaths. According to Hare (in Stover 2008: 157) Pasychopaths life as a parasite to take other for their happiness.

Data 15 :

'Oh, but Paul" she said, turning to him, her eyes dancing animatedly in her flushed face. 'I don't think, I know! You're going to use this typewriter to write a new novel! Your best novel! Misery's Retum!' 'It will be a book just for me, Paul! 'I'm going to study up on book-binding,' she said dreamily. 'I'm going to bind Misery's Return myself. Except for my mother's Bible, it will be the only real book I own.' (pg. 24)

In data 15, the quotation was shows the parasitic lifestyle in Annie. This is proved when She locked Paul in her house for weeks. This crime is done by Annie to fulfill her personal satisfaction. Annie is very much in love with Paul Sheldon's Misery novel. Bad things began to happen to Paul after Annie found the end of Misery's story that does not match with what she expected. Annie makes used of Paul Sheldon by forcing her to retype the Misery novel. The novel was entitled Misery Return- By Paul Shaldon- For Annie Wilkes. The data is relevant with Hare's that psychopaths life as a parasite to take other for their happiness.

Data 16 :

He was already nine pages into Chapter 7 - Geoffrey and Mrs Ramage had managed to get Misery out of her grave in the barest nick of time only to realize that the woman had no idea at all who they were, or who she herself was - when Annie came into the room. This time Paul heard her. He stopped typing, sorry to be out of the dream. (pg. 7 C.II) 
In data 16, the quotation proved that Paul really fulfill Annie's satisfication. He followed Annie's rule. He retype the novel and it was in Chapter 7. The data is supported Hare's theory that psychopaths life as a parasite to take other for their happiness.

\section{Have a Cruel Social Relationship with Others}

Crime is a psychopathic habit. According to Hare (in Pemayun 2017: 422) The form of cruelty in psychopath is crime. Psychopaths commited a crime like deceptioned, tortured and even killed. They done a lot of criminal acts with a certain motivation or purpose, without hesitation and without choosed anyone who will be the victim. They did it easily because they're used to did it before.

Data 18 :

'I washed ... well . . what was left of him . . and his clothes. I knew what to do. It was snowing outside, the first real snow of the year, and they said we'd have a foot by the next morning. I put his clothes in a plastic bag and wrapped the body in sheets and took everything out to that dry wash on Route 9 after dark. I walked about a mile farther down from where your car ended up. I walked until I was in the woods and just dumped everything. You probably think I hid him, but I didn't. I knew the snow would cover him up, and I thought the spring melt would carry him away if I left him in the stream-bed. (pg. 21)

In data 18, Annie confess her crime to Paul that she had killed a man and removed her trail. She admitted it by explained the incident. She cleaned his fingerprints on the clothes and body of the victim and then throw them into the river to carry the river flow. In this case, proved that Annie was killed a man. The data is supported Hare's theory that, because of there is no sense of empathy in psychopaths, making them capable to commited a crime like killing. 


\section{Data 19:}

She would have only the vaguest memories of what she had done, as she had only the vaguest memories of killing the children and the old people and the terminal patients and Andrew Pomeroy. After all, this was the woman who, although she'd gotten her cap in 1966, had told him only minutes ago that she had been a nurse for ten years. She killed Pomeroy with that same axe. I know she did. (pg. 22)

In data 19, the quotation was about Paul's statement that Annie killed the children, old people, terminal patient and also Andrew Pomeroy. The data is relevant withHare's theory that because of there is no sense of empathy in psychopaths, making them capable to commited a crime like killing.

\section{Anti- Social}

Concerned with socialization relationship, Hare (in Pemayun 2017: 422) said that generally, psychopaths have no good relationship with others. The theory was relevant with Annie's act who has bad relationship with others.

Data 21 :

They were miles from the neighbors who, Annie said didn't like her. What was the name? Boynton. No, Roydman. That was it. Roydman. And how far from the town? Not too far, surely. He was in a circle whose diameter might be as small as fifteen miles, or as large as forty-five..." (pg. 29)

In data 21, the quotation was about Annie's statement to Paul that her neighbors did not like her. It proved that she has no good relationship with others especially with her neighbors. Proved that Annie has psychopathic trait, antisocial. This data is supported Hare's theory that generally, psychopaths have no good relationship with others.

\section{CONCLUSION AND SUGGESTION}

\section{Conclusion}

In "Misery" novel by Stephen King, the researcher make a conclusion of what has been analyzed in the previous chapter. 
Annie Wilkes as the main character in the Misery novel, has a personality disorder especially in abnormal behavior. The abnormal behavior that Annie did to Paul as her victim, concerned with the traits of the psychopath put forward by R. D. Hare in his psychopathy checklist theory.

From twelve psychopathic checklist by Robert D. Hare, it was eleven pschopathy traits that exist in character of Annie Wilkes. That are egocentric, lack of empathy, lack of concern for others, impulsivity, poor behavioral control, have an attractive outward appearance, shallow emotions, have no fear, high posses feelings for personal satisfication, have a cruel social relationship with others and anti- social.

\section{Suggestion}

To the researcher, you can use this research to add the reference about the psychopathic traits, for doing a research when you will analyzing the literary works, especially in analyzing the psychopathic traits.

To the reader, this novel is very good to read because there are many psychopathic traits was showed by the main character. The researcher hope, when the reader read this research, the reader can understand the psychopathic traits shows by the main character in thi novel.

\section{REFERENCES}

Alwisol. (2009). Psikologi Kepribadian. Malang: UMM Press.

Ary, D. Jacoubs. (1985). Pengantar Penelitian dalam Pendidikan. Surabaya: Usaha Nasional

Barlow, D.H. (2006). Intisari Psikologi Abnormal. Edisi IV. Yogyakarta: Pustaka Pelajar.

Chaer, Ellie. (2003). Mempelajari Psikologi Manusia. Bandung: PT Remaja Rosdakarya.

Creswell, John W. (2003). Research Design: qualitative, quantitave, and method approached. Sage Publication, Inc: California.

Dirgagunarsa, Singgih. (1983). Pengantar Psikologi. Jakarta: Mutiara. 
Fausiyah, Fitri \& Widury, Julianty. 2008. Psikologi Abnormal. Jakarta: Universitas Indonesia (UI-Press).

Heuken, Adolf. (1979). Tantangan Membina Keribadian (Pedoman Mengenal Diri). Yogyakarta: Kanisius.

Herdiansyah, Haris. (2010). Metodologi Penelitian Kuantitatif. Jakarta: Salemba Humanika.

Hirstein, William. (2005). Brain Fiction: Self-deception and the Riddle of Confabulation. Hongkong: MIT Press

Jacoubs, Janira Beye. (2009). Factor Structure of the Psychopathy Checklist Revised in Female Insanity Acquittees. United States: ProQuest

Larsen, Randy J.,\& David M. Buss. (2008). Personality Psychology: Domains of Knowledge About Human Nature. New York: Mc Grow- Hill

Minderop, Albertine. (2010). Psikologi Sastra (Karyasastra, Metode, Teori dan ContohKasus). Jakarta : Yayasan PustakaObor Indonesia.

Mustofa, Ali. (2009). Martin's Psychopathic Disorder In The Girl With The Dragon Tattoo. Journal of Psychology, 19- 20.

Wahid, Rosin Novaditya Nur. (2016) The Psychopath Phenomenon Reflected In Gillian Flynn's Gone Girl. Journal Publication, 19, 417-425.

Perri, Justin \& Lichtenwald. (2010). Human Behavior. New York: Export University Press.

Stover, R.H. (2008). Psychopath Traits. Jakarta : Prestasi Pustaka

Wellek, Rene dan Austin Warren. (1989). Teori Kesusastraan (edisi terjemahan oleh Melani Budianta). Jakarta: Gramedia

Widodo, Suparno. (2015). Metode Penelitian. Yogyakarta: Pustaka Pelajar 